\title{
Leisure Boredom dan Religiusitas: Pengaruhnya terhadap Kecenderungan Adiksi Internet
}

\author{
Azti Verina Noor Azizah Kosasih, Sarbini, Agus Mulyana \\ Fakultas Psikologi, Universitas Islam Negeri Sunan Gunung Djati Bandung, Indonesia \\ e-mail: agus.mulyana@uinsgd.ac.id
}

\begin{abstract}
The internet is an unavoidable necessity. There are positive and negative impacts of internet. One of the negative impacts is addiction. Reasons for someone become addicted to the internet including leisure boredom and religiosity. This study aims to determine whether leisure boredom and religiosity have an influence on the internet addiction in students of UIN Sunan Gunung Djati Bandung. The research method used a quantitative causality design which is analyzed using multiple regression. The study was conducted on 265 students recruited using the accidental sampling method. The measurement uses three scales, the Leisure Boredom Scale, The Centrality of Religiosity Scale, then the Internet Addiction Test. The results showed that leisure boredom and religiosity had significant influence on internet addiction. Influence given is 5.3\%. This finding indicates that leisure boredom and religiosity affect someone to become internet addicted by 5.3\%, Meanwhile, 94.7\% of other factors that influence addiction to the internet may still need further research.
\end{abstract}

Keywords: leisure boredom, religiosity, internet addiction

\begin{abstract}
Abstrak
Internet merupakan kebutuhan yang tidak bisa dielakkan. Manfaatnya begitu banyak meskipun terdapat pula dampak negatifnya, salah satunya adalah adiksi. Begitu banyak penyebab seseorang menjadi adiksi terhadap internet diantaranya adalah leisure boredom dan juga religiusitas. Penelitian ini bertujuan untuk mengetahui apakah leisure boredom dan religiusitas memiliki pengaruh terhadap adiksi internet pada mahasiswa UIN Sunan Gunung Djati Bandung. Metode penelitian menggunakan rancangan kuantitatif kausalitas yang dianalisis menggunakan regresi berganda. Penelitian dilakukan kepada 265 orang mahasiswa yang didapat dengan menggunakan metode accidental sampling. Pengukuran menggunakan tiga skala yaitu Leisure Boredom Scale, The Centrality of Religiosity Scale dan Internet Addiction Test. Hasil penelitian menunjukkan bahwa leisure boredom dan religiusitas memiliki pengaruh signifikan terhadap adiksi internet. Besarnya pengaruh yang diberikan sebesar 5.3\%. Artinya, leisure boredom dan religiusitas memengaruhi seseorang untuk menjadi adiksi internet sebesar 5.3\%. Terdapat $94.7 \%$ faktor lain yang memengaruhi adiksi terhadap internet yang masih perlu dilakukan penelitian lebih lanjut.
\end{abstract}

Kata Kunci: leisure boredom, religiusitas, adiksi internet

\section{Pendahuluan}

Seiring dengan berkembangnya zaman, kemajuan teknologi dari tahun ke tahun semakin meningkat. Teknologi yang semakin canggih ini mampu memfasilitasi para penggunanya dalam menggunakan internet untuk memenuhi kebutuhannya. Berdasarkan pada laporan data hasil riset lembaga internasional We Are Social (2020) mengenai kondisi digital secara global, didapatkan 64\% (175.3 juta jiwa) penduduk Indonesia adalah pengguna internet. Data lain memperlihatkan bahwa 98\% (171 juta jiwa) dari pengguna internet tersebut mengakses internet melalui gawai. Dari jumlah tersebut memperlihatkan bahwa pengguna internet di Indonesia tergolong banyak. Lebih dari setengah warga negara Indonesia menggunakan internet dan hampir keseluruhannya mengakses menggunakan gawai. 
Penggunaan internet ini diperkuat oleh adanya pandemi yang terjadi pada awal Maret 2020, Indonesia mendapatkan kasus Covid-19 pertama yang hingga saat ini masih belum terselesaikan. Hal tersebut membuat semua masyarakat diharuskan untuk berdiam diri di rumah dan melakukan social distancing. Akibat kebijakan social distancing ini, individu harus menggunakan internet untuk melakukan rutinitas seharihari, mulai dari bersosialisasi, berkumpul, melakukan aktivitas keagamaan, hingga belajar. Internet adalah salah satu saluran utama untuk memperbarui informasi COVID-19 serta alat pembelajaran online (Indriawati \& Wibowo, 2021).

Berdasarkan hasil survei Asosiasi Penyelenggara Jasa Internet Indonesia (2020), jumlah penggunaan internet selama pandemi sebesar 196.71 juta jiwa dengan persentase penetrasi $73.7 \%$ dari populasi 266.91 juta jiwa penduduk Indonesia. Penggunaan internet meningkat selama pandemi COVID-19 (Indriawati \& Wibowo, 2021).

Penggunaan internet dalam waktu yang lama dan menjadi kebiasaan dengan terus-menerus berselancar di internet, dalam Psikologi disebut dengan adiksi internet. Istilah adiksi internet pertama kali dikemukakan oleh Young (1998). Adiksi didefinisikan sebagai gangguan kontrolimpuls namun tidak melibatkan zat yang memabukkan. Adiksi internet umumnya memiliki karakteristik seperti keasyikan yang tidak terkontrol dengan internet, gejala penarikan ketika internet diambil, toleransi, penggunaan internet yang berlebihan, kehilangan minat, dan upaya yang gagal mengendalikan penggunaan internet (Weinstein \& Lejoyeux, 2010). Seseorang dikatakan adiksi terhadap internet, ketika penggunaan internet mencapai lebih dari 6 jam perhari yang digunakan untuk browsing, bermain sosial media, mencari berita, menonton youtube, berkomunikasi, online shopping, dan bermain game online diluar aktivitas mengerjakan tugas sekolah atau pekerjaan maupun bisnis (Tao dkk., 2010).

Beberapa dampak adiksi internet diantaranya: gangguan mental seperti kecemasan, depresi, isolasi dan kehilangan harga diri, kurang tidur, tidak makan dalam waktu yang lama, dan kendala dalam aktivitas fisik (Gorgich dkk., 2018). Asosiasi Penyelenggara Jasa Internet Indonesia (2018) melakukan survei yang hasilnya menunjukkan bahwa pengguna internet terbanyak di Indonesia berdasarkan tingkat pendidikan adalah kelompok yang sedang kuliah dengan penetrasi sebesar 92.6\%. Terbanyak kedua yaitu kelompok yang duduk di Sekolah Menengah Atas (SMA) sebesar 90.2\%. Kelompok Sekolah Menengah Pertama (SMP) sebesar 80.4\% dan kelompok Sekolah Dasar (SD) sebesar $41.4 \%$.

Kelompok yang sedang kuliah ini adalah mahasiswa. Dalam hal ini berarti mahasiswa bisa berisiko kecanduan internet. Young (2004) menyatakan bahwa kelompok risiko tertinggi untuk kecanduan internet adalah mahasiswa. Hal itu disebabkan tersedianya waktu luang yang tidak disertai dengan pengawasan dari orang tua. Mahasiswa juga memiliki fitur yang lebih spesifik karena mereka harus belajar selama berjam-jam.

Saat pandemi ini, mahasiswa dapat mengalami adiksi internet karena harus sering berinteraksi dengan internet. Hal itu terjadi saat mahasiswa belajar dari rumah maupun untuk mengisi waktu luang mereka. Salah satu pilihan mahasiswa dalam mengisi waktu luang adalah dengan berselancar di internet sehingga sangat memungkinkan mahasiswa mengalami adiksi internet mengingat persentase penggunaan internet lebih besar daripada tingkat pendidikan lainnya.

Faktor yang menyebabkan mahasiswa menggunakan internet yaitu dalam keadaan bosan dan waktu senggang. Menurut Zhou dan Leung (2012), mahasiswa telah menghabiskan waktu luangnya dengan berselancar di internet 
atau bermain video game dan telah menggantikan bentuk kegiatan sosial lainnya. Secara tersirat, dapat disimpulkan bahwa adanya kebutuhan untuk mengisi waktu luang membuat mahasiswa terusmenerus berselancar di internet.

Menurut Iso-Ahola dan Weissinger (1990), leisure boredom atau kebosanan pada waktu luang adalah persepsi subjektif atau suasana hati yang negatif disebabkan adanya ketidakcocokan antara ketersediaan waktu luang dan kebutuhan akan pengalaman yang optimal. Leisure boredom hanya memiliki satu dimensi yaitu perasaan individu terhadap waktu senggang, frekuensi aktivitas atau kegiatan yang dilakukan oleh individu dalam waktu senggang, dan kebutuhan sosial atas pengalaman optimal pada waktu senggang yang dimiliki.

Berdasarkan temuan Kara (2019), adiksi internet berpihak pada individu yang tidak melakukan aktivitas fisik dalam mengatasi kebosanan waktu senggangnya. Ketika mahasiswa bosan atau tidak puas dengan waktu luang mereka, mereka mungkin termotivasi untuk mencari kesenangan dari dunia maya sehingga dapat meningkatkan tingkat kecanduan internet mereka. Dari beberapa penelitian tersebut menunjukkan bahwa kebosanan di waktu luang memberikan kesempatan pada mahasiswa untuk berselancar di internet sehingga dapat meningkatkan kecenderungan terjadinya kecanduan internet.

Faktor lain yang dapat memengaruhi tingkat adiksi internet adalah religiusitas. Basri (2014) menjelaskan bahwa religiusitas dapat memengaruhi dan berkontribusi bagi tingkat kecenderungan adiksi internet pada mahasiswa. Seseorang yang mengalami adiksi internet menjadi abai terhadap pelaksanaan ibadah sholat. Ketika sedang asyik mengakses internet, walaupun adzan telah berkumandang mereka tetap asyik mengakses internet sehingga menunda-nunda pelaksanaan ibadah sholat yang akhirnya dikerjakan di akhir waktu.
Menurut Huber dan Huber (2012), religiusitas mengacu pada intensitas, artipenting, kepentingan atau sentralitasnya dalam individu. Yang paling umum adalah skala item tunggal yang meminta laporan diri tentang kepentingan subjektif agama atau arti penting identitas agama, misalnya, seberapa penting agama bagi Anda atau seberapa religius Anda menganggap terhadap diri sendiri. Dapat disimpulkan bahwa religiusitas menurut Huber dan Huber adalah intensitas individu dalam menjalankan perintah agama, seberapa penting agama bagi individu, penghayatan dan keyakinan individu terhadap agamanya. Menurut Huber dan Huber (2012), religiusitas terdiri dari lima dimensi yaitu intelektual, ideologi, praktik publik, praktik pribadi, dan pengalaman religius.

Wijesingha dkk. (2017) menyatakan bahwa keyakinan spiritual dapat memengaruhi risiko kecanduan internet dengan cara yang sama seperti perjudian online yang menjadi semakin sering terjadi pada remaja dengan peningkatan aksesibilitas internet. Nadeem dkk. (2019) menyatakan bahwa tingkat religiusitas individu memiliki hubungan negatif dengan internet, dengan religiusitas instrinsik individu dapat menurunkan penggunaan internet di kalangan dewasa muda. Hal itu didukung oleh Charlton dkk. (2013) bahwa individu dengan religiusitas yang lebih besar memiliki kecenderungan kecanduan internet lebih rendah. Beberapa penelitian tersebut menjelaskan bahwa religiusitas memiliki arah yang berlawanan dengan adiksi internet.

Kedua variabel tersebut, leisure boredom dan religiusitas memiliki pengaruh terhadap adiksi internet dengan arah yang berbeda. Leisure boredom dapat meningkatkan adiksi seseorang dalam menggunakan internet karena tidak ada aktivitas yang dilakukan. Di sisi lain, religiusitas dapat menghambat seseorang menjadi adiksi terhadap internet.

Sejauh ini, belum ditemukan ada penelitian yang meneliti kedua variabel 
tersebut secara bersamaan, mengenai bagaimana tingkat religiusitas dan leisure boredom pada seorang yang mengalami adiksi internet berdasarkan standar waktu yang dikemukakan Tao dkk. (2010). Hal itu mendorong peneliti untuk mengetahui bagaimana interaksi dari ketiga variabel tersebut. Penelitian ini bertujuan untuk megetahui bagaimana pengaruh dari leisure boredom dan religiusitas terhadap kecenderungan adiksi internet pada mahasiswa.

\section{Metode Penelitian}

Pendekatan kuantitatif dengan jenis penelitian kausalitas merupakan pendekatan yang digunakan dalam penelitian. Populasi penelitian ini adalah mahasiswa aktif UIN Sunan Gunung Djati Bandung berjumlah 27.766 mahasiswa yang tersebar di sembilan fakultas. Sampel penelitian yang terkumpul dari teknik accidental sampling berjumlah 265 orang. Subjek yang menjadi sampel penelitian diambil berdasarkan kriteria berikut: (1) Mahasiswa aktif UIN SGD Bandung; (2) Mengakses internet setiap hari pada perangkat apapun (handphone, laptop, tablet dan lain-lain); serta (3) Menggunakan internet dalam waktu lebih dari 6 jam diluar keperluan akademik dan bisnis (berdasarkan pengakuan subjek).

Pengumpulan data dilakukan dengan menyebar kuesioner secara online melalui google form. Penelitian menggunakan tiga alat ukur. Alat ukur pertama adalah Leisure Boredom Scale dari Iso-Aloha dan Weisseinger (1990) untuk mengukur leisure boredom. Hal yang digali adalah perasaan individu mengenai waktu senggang yang dimiliki. Alat ukur terdiri dari 14 pernyataan baik dan berdasarkan hasil uji statisktik didapatkan nilai validitas 1.0 sedangkan reliabilitas .791. Subjek menilai pernyataan menggunakan skala dengan rentang 1 (sangat tidak setuju) sampai dengan 5 (sangat setuju). Contoh item, "Waktu luang membosankan, saya menghabiskan banyak waktu luang untuk tidur".

Untuk mengukur religiusitas, alat ukur yang digunakan adalah The Centrality of Religiosity Scale dari Huber dan Huber (2014). Alat ukur ini terdiri dari 5 dimensi, yaitu intellectual, ideology, public practice, private practice dan religion experience. Terdiri dari 14 pertanyaan dimana subjek menilai dalam rentang 1 (tidak pernah) sampai dengan 5 (selalu). Dari hasil pengukuran didapatkan validitas untuk masing-masing dimensi yaitu: intellectual .659 , ideology .620 , public practice .822 , private practice .801, dan religion experience .727 , dengan hasil reliabilitas sebesar .853. Contoh itemnya, "Seberapa sering Anda ikut serta dalam ibadah?", dan "Seberapa sering Anda berdoa?".

Adiksi internet diukur menggunakan Internet Addiction Test versi Indonesia dari Rakhmat (2018). Alat ukur terdiri dari 19 pertanyaan. Terdapat 6 dimensi yang digali, yaitu: salience, excessive use, neglect work, anticipation, lack of control, dan neglect social life. Subjek menilai pernyataan dengan rentang 1 (tidak pernah) sampai dengan 5 (selalu). Reliabilitas alat ukur ini sebesar .872, sedangkan validitas setiap dimensi yaitu: salience .849 , excessive use .784, neglect work .693, anticipation .697 , lack of control .821, dan neglect social life .582. Contoh item, "Seberapa sering Anda lebih memilih online daripada keluar dengan teman-teman", dan "Seberapa sering Anda kehilangan jam tidur karena bergadang demi bisa online saat malam".

Analisis statistik deskriptif dan analisis inferensial regresi berganda dilakukan untuk menganalisis data. Dalam analisis deskriptif perhitungan mean dan standar deviasi dilakukan untuk masing-masing variabel. Selanjutnya, skor dibagi ke dalam tiga kategori yaitu tinggi, sedang dan rendah. Analisis inferensial dilakukan dengan menghitung analisis regresi berganda setelah melewati uji asumsi klasik yaitu uji normalitas, uji multikolinearitas, uji heterokedastisitas, dan uji autokorelasi. 
Selanjutnya menghitung koefisien determinasi, uji $\mathrm{F}$ (simultan) dan uji $\mathrm{t}$ (parsial).

\section{Hasil Penelitian dan Pembahasan}

\section{Hasil}

Subjek penelitian ini adalah mahasiswa UIN Sunan Gunung Djati Bandung. Subjek terdiri dari $203(76.6 \%)$ perempuan dan 62 (23.4\%) laki-laki. Subjek penelitian berada pada semester yang beragam yang mana mahasiswa semester 7 menjadi responden terbanyak yaitu 108 orang $(40.8 \%)$. Adapun yang paling sedikit adalah mahasiswa semester 9 yaitu 6 orang (2.3\%). Sebaran subjek berdasarkan semester lebih jelasnya tersaji pada tabel 1 .

Tabel 2 memperlihatkan lama waktu penggunaan internet oleh subjek. Waktu penggunaan internet beragam mulai dari paling sedikit 6 jam sampai paling banyak 18 jam. Peneliti membagi lama waktu penggunaan internet menjadi 3 kategori yaitu rendah, sedang dan tinggi dengan membuat rentang dari 6 jam sampai 18 jam. Lebih jelasnya dapat dilihat pada tabel 2 .

Tabel 1

Gambaran Umum Sampel berdasarkan Semester

\begin{tabular}{lcc}
\hline Semester & Frekuensi & Persentase \\
\hline 1 & 46 & $17.3 \%$ \\
3 & 41 & $15.5 \%$ \\
5 & 64 & $24.1 \%$ \\
7 & 108 & $40.8 \%$ \\
9 & 6 & $2.3 \%$ \\
\hline
\end{tabular}

Tabel 2

Gambaran Umum Sampel berdasarkan Lama Waktu Penggunaan Internet (Non Akademik \& Non Bisnis)

\begin{tabular}{lcc}
\hline $\begin{array}{c}\text { Lama Waktu } \\
\text { (jam) }\end{array}$ & $\begin{array}{c}\text { Frekuensi } \\
\text { (orang) }\end{array}$ & $\begin{array}{c}\text { Persentase } \\
(\%)\end{array}$ \\
\hline Rendah (6-9) & 197 & 74.4 \\
Sedang (10-13) & 49 & 18.5 \\
Tinggi (> 13) & 19 & 7.1 \\
\hline
\end{tabular}

Tabel 3

Statistik Deksriptif Variabel Penelitian

\begin{tabular}{lccccc}
\hline \multicolumn{1}{c}{ Variabel } & $\mathrm{N}$ & $\mathrm{Min}$ & $\mathrm{Max}$ & Mean & Std. Dev. \\
\hline $\begin{array}{l}\text { Leisure } \\
\text { Boredom }\end{array}$ & 265 & 26 & 58 & 40.95 & 6.066 \\
$\begin{array}{l}\text { Religiusitas } \\
\text { Adiksi }\end{array}$ & 265 & 21 & 70 & 57.73 & 6.356 \\
\begin{tabular}{l} 
Internet \\
\hline
\end{tabular} & 265 & 30 & 92 & 54.88 & 11.598 \\
\hline
\end{tabular}

Tabel 4

Kategori Variabel Penelitian

\begin{tabular}{lccc}
\hline \multicolumn{1}{c}{ Variabel } & Kategori & Frekuensi & Persentase \\
\hline $\begin{array}{l}\text { Leisure } \\
\text { Boredom }\end{array}$ & Rendah & 22 & $8.3 \%$ \\
& Sedang & 227 & $85.7 \%$ \\
& Tinggi & 16 & $6 \%$ \\
Religiusitas & Rendah & 2 & $.8 \%$ \\
& Sedang & 28 & $10.5 \%$ \\
& Tinggi & 235 & $88.7 \%$ \\
Adiksi & Rendah & 45 & $17 \%$ \\
& Sedang & 190 & $71.7 \%$ \\
& Tinggi & 30 & $11.3 \%$ \\
\hline
\end{tabular}

Selanjutnya dilakukan perhitungan mean, standar deviasi, skor minimun dan maximum dari setiap variabel penelitian menggunakan aplikasi SPSS yang disajikan pada tabel 3. Dari 265 subjek, skor terendah variabel adiksi internet sebesar 30 dan skor tertingginya sebesar 92. Sedangkan skor terendah variabel leisure boredom sebesar 26 dan skor tertinggi 58. Selanjutnya, skor terendah untuk variabel religiusitas sebesar 21 dan skor tertinggi 70. Setelah mengetahui nilai mean dan standar deviasi masing-masing variabel, peneliti membuat norma untuk mengklasifikasikan responden ke dalam kategori rendah, sedang dan tinggi.

Berdasarkan kategori variabel penelitian pada tabel 4 , persentase terbesar yang diperoleh pada kategori sedang, terdapat pada variabel leisure boredom yaitu sebesar $85.7 \%$ serta variabel kecenderungan adiksi internet sebesar $71.7 \%$. Berbeda halnya dengan variabel religiusitas, yang mana persentase terbesar terdapat pada kategori tinggi yaitu sebesar $88.7 \%$. 


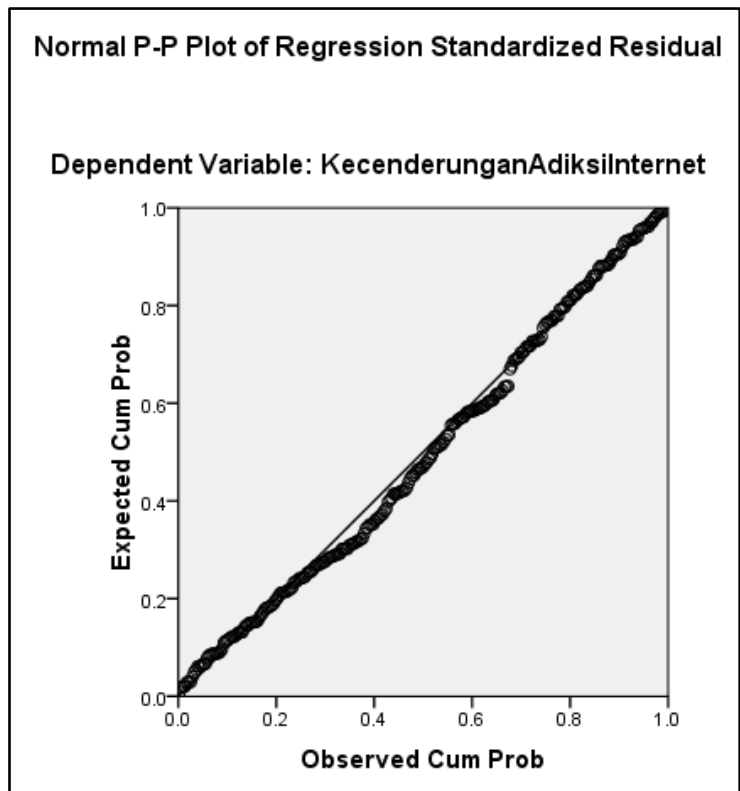

Gambar 1. Hasil uji normalitas

Selanjutnya disajikan hasil perhitungan uji asumsi klasik yang terdiri dari uji normalitas, uji multikolinearitas, uji heterokedastisitas dan uji autokorelasi.Uji normalitas dilakukan dengan melihat grafik Normal P-P Plots of Regression Standardized Residual dengan aplikasi SPSS. Hasil menunjukkan data berdistribusi normal karena data menyebar di sekitar diagonal dan mengikuti arah garis diagonal seperti yang terlihat pada gambar 1 .

Pada uji multikolinearitas diperoleh Nilai tolerance pada masing-masing variabel adalah $.959>.10$ dan nilai VIF dari setiap variabel adalah 1.043. Dengan demikian dapat disimpulkan bahwa tidak terjadi multikolinearitas pada variabelvariabel penelitian.

Selanjutnya hasil uji heterokedastisitas menunjukkan scatterplot tidak membentuk sebuah pola dan titik-titik yang tersebar di atas dan di bawah sumbu Y sehingga dapat dikatakan bahwa tidak terjadi heterokedastisitas.

Terakhir, uji autokorelasi menggunakan uji Durbin Watson, diperoleh nilai DW sebesar $1.808<2.133<2.192$. Hal tersebut menunjukkan bahwa tidak terjadi autokorelasi pada variabel-variabel penelitian.

Hasil perhitngan uji $t$ parsial menunjukkan bahwa variabel leisure boredom mendapatkan nilai signifikansi sebesar $.000<.05$ artinya leisure boredom berpengaruh secara signifikan terhadap adiksi internet. Sedangkan variabel religiusitas mendapatkan nilai signifikansi sebesar $.206>.05$ artinya religiusitas tidak berpengaruh secara signifikan terhadap adiksi internet.

Hasil perhitungan uji $\mathrm{F}$ simultan menunjukkan bahwa variabel leisure boredom dan religiusitas mendapatkan nilai signifikansi sebesar $.001<.05$ artinya leisure boredom dan religiusitas berpengaruh signifikan secara bersamasama terhadap adiksi internet.

Hasil perhitungan koefisien determinasi sebesar .053 atau 5.3\%. Artinya leisure boredom dan religiusitas berpengaruh terhadap kecenderungan adiksi internet sebesar $5.3 \%$, sedangkan sisanya $94.7 \%$ dipengaruhi oleh variabel lain.

Hasil model persamaan regresi sebagai berikut: (1) nilai konstanta adalah 28.391, artinya jika tidak terjadi perubahan variabel leisure boredom (X1) dan religiusitas (X2) nilainya 0 maka kecenderungan adiksi internet pada mahasiswa UIN Sunan Gunung Djati Bandung ada sebesar 28.391, (2) nilai koefisien regresi leisure boredom adalah .447, artinya jika variabel leisure boredom (X1) meningkat sebesar 1 satuan dengan asumsi nilai variabel lain tetap maka kecenderungan adiksi internet juga akan meningkat sebesar .447, (3) nilai koefisien regresi religiusitas adalah .142, artinya jika variabel religiusitas (X2) meningkat sebesar 1 satuan dengan asumsi nilai variabel lain tetap maka kecenderungan adiksi internet juga akan meningkat sebesar .142.

\section{Pembahasan}

Berdasarkan hasil perhitungan, sebanyak $8.3 \%$ subjek memiliki tingkat 
leisure boredom rendah, $85.7 \%$ subjek memiliki tingkat leisure boredom sedang dan $6 \%$ lainnya memiliki tingkat leisure boredom tinggi. Hal ini menunjukkan bahwa banyak mahasiswa yang memiliki tingkat leisure boredom sedang sehingga dapat disimpulkan bahwa banyak mahasiswa UIN Sunan Gunung Djati Bandung memiliki kebosanan saat mengisi waktu luang. Namun, adapula mahasiswa yang mengisi waktu luangnya dengan kegiatan lain sehingga mereka tidak memilliki rasa bosan dalam waktu luangnya.

Variabel independen lainnya yang diteliti dalam penelitian adalah religiusitas. Subjek dengan tingkat religiusitas rendah didapati sebesar $.8 \%$, subjek dengan tingkat religiusitas sedang sebesar $10.5 \%$ dan subjek dengan tingkat religiusitas tinggi sebesar $88.7 \%$. Hal ini menunjukkan bahwa lebih banyak mahasiswa UIN Sunan Gunung Djati Bandung yang memiliki religiusitas tinggi sesuai dengan title universitas Islam dengan sistem pendidikan yang menanamkan nilai-nilai Islam di dalamnya. Individu dengan religiusitas tinggi memiliki pengetahuan, pemahaman, penghayatan dan keyakinan atas agamanya yang tinggi serta melaksanakan berbagai kegiatan agama dalam kesehariannya.

Selanjutnya hasil perhitungan tingkat adiksi internet mahasiswa UIN Sunan Gunung Djati Bandung diperoleh sebesar $17 \%$ untuk subjek dengan tingkat adiksi internet rendah, $71.7 \%$ subjek dengan tingkat adiksi internet sedang dan $11.3 \%$ untuk subjek dengan tingkat adiksi internet tinggi. Hal ini menunjukkan bahwa lebih banyak mahasiswa UIN Sunan Gunung Djati Bandung yang mengalami kesulitan dalam mengontrol penggunaan internet mereka sehingga mahasiswa mengakses internet dalam waktu yang lama, mengabaikan dunia nyata dan mengalami permasalahan dalam hubungan sosial. Sedangkan mahasiswa lainnya masih dapat mengontrol dalam penggunaan internet mereka yang dibuktikan dengan tingkat adiksi yang rendah.

Berdasarkan pada hasil perhitungan koefisien determinasi $\left(\mathrm{R}^{2}\right)$, koefisien determinasi penelitian ini sebesar .053 atau 5.3\%. Artinya leisure boredom dan religiusitas berpengaruh terhadap kecenderungan adiksi internet sebesar $5.3 \%$, sedangkan sisanya $94.7 \%$ dipengaruhi oleh variabel lain. Hal itu menunjukkan bahwa kecenderungan adiksi internet pada mahasiswa UIN Sunan Gunung Djati Bandung terjadi oleh berbagai variabel lain selain leisure boredom dan religiusitas.

Pengaruh yang diberikan oleh leisure boredom dan religiusitas terhadap kecenderungan adiksi internet sebesar 5.3\% menunjukkan pengaruh yang dapat dikatakan kecil. Hal ini terlihat dari sebaran kategorisasi pada leisure boredom dan kecenderungan adiksi internet yang lebih banyak pada tingkat kategori sedang serta sebaran kategorisasi pada religusitas yang lebih banyak pada tingkat religiusitas tinggi.

Hasil perhitungan uji parsial pada variabel leisure boredom menunjukkan bahwa leisure boredom memiliki pengaruh terhadap kecenderungan adiksi internet pada mahasiswa UIN Sunan Gunung Djati Bandung. Semakin tinggi nilai leisure boredom seseorang maka akan semakin meningkat nilai adiksi internetnya. Hasil tersebut mendukung hasil penelitian sebelumnya oleh Kara (2019) bahwa adiksi internet berpihak pada individu yang tidak melakukan aktivitas fisik dalam mengatasi kebosanan dalam waktu senggangnya. Dengan demikian dapat disimpulkan bahwa individu dengan kecenderungan adiksi internet dapat meningkatkan penggunaan internet ketika individu tidak tahu apa yang harus dilakukan dalam mengatasi kebosanan dalam waktu senggang dan gagal dalam memenuhi kebutuhannya sehingga individu menggunakan internet sebagai solusi dalam mengatasi hal tersebut. 
Sementara itu hasil penelitian ini juga memperkuat hasil penelitian Pari dan Jami (2018) bahwa religiusitas menahan individu untuk menggunakan internet, sehingga mengurangi kemungkinan mereka mengembangkan adiksi internet. Dengan begitu, individu yang memiliki religiusitas tinggi dapat menahan individu dalam penggunaan internet dan dapat menurunkan risiko kecenderungan adiksi internet.

Hal tersebut dapat terjadi karena subjek yang digunakan dalam penelitian adalah mahasiswa yang sedang melakukan pembelajaran daring, mengingat pada saat ini semua aktivitas dilakukan secara online sehingga ketika ada waktu luang kemungkinan mahasiswa mengisi waktunya dengan mengakses internet.

Jika melihat dari gambaran subjek penelitian, peneliti menduga bahwa pengaruh ini bisa terjadi karena subjek penelitian ini kebanyakan adalah mahasiswa semester 7, yang mana mahasiswa semester 7 ada yang sudah tidak memiliki kelas kuliah, dan sekalipun masih ada kelas, namun tidak terlalu banyak seperti semester-semester sebelumnya sehingga memiliki lebih banyak waktu luang. Dengan demikian, temuan ini menyatakan bahwa mahasiswa yang memiliki waktu luang banyak kemudian merasa bosan dalam waktu luangnya cenderung menggunakan internet secara berlebihan dan mereka gagal dalam mengatur penggunaan internet tersebut.

Hasil perhitungan uji parsial untuk variabel religiusitas menunjukkan religiusitas tidak berpengaruh secara signifikan terhadap kecenderungan adiksi internet pada mahasiswa UIN Sunan Gunung Djati Bandung. Hasil ini bertentangan dengan Wijesingha dkk. (2017), Nadeem dkk. (2019) dan Charlton dkk. (2013) bahwa individu dengan religiusitas yang lebih besar memiliki kecenderungan kecanduan internet yang lebih rendah. Berbeda dengan penelitian sebelumnya, penelitian ini menemukan bahwa seseorang dengan religiusitas tinggi pun dapat mengalami adiksi internet. Hal itu dapat dilihat dari $88.7 \%$ subjek memiliki nilai religiusitas tinggi.

Temuan hasil pada penelitian ini bahwa seseorang dengan religiusitas yang tinggi pun dapat mengalami adiksi terhadap internet memperlihatkan bahwa saat ini internet sudah tidak bisa dilepaskan dari keseharian seseorang. Tanpa melihat kualitas dari religiusitas seseorang, penelitian ini membuktikan bahwa adiksi terhadap internet dapat terjadi kepada siapa saja. Di sisi lain, kondisi pandemi Covid-19 yang mengharuskan seseorang membatasi kegiatan di luar rumah dan lebih banyak berdiam diri di rumah dapat memicu terjadinya adiksi terhadap internet.

Media hiburan dan sosial media saat ini tidak lepas dari peran internet di dalamnya. Seseorang yang mengalami kejenuhan akan menjadikan internet sebagai media hiburan. Selain itu, kajian keagamaan saat ini pun banyak disebarkan melalui internet sehingga hal itu semakin memicu seseorang untuk mengakses internet saat mengikuti kegiatan keagaaman, terutama dalam menambah pengetahuan dan pemahaman mengenai agama.

Selain temuan yang didapat dari penelitian ini, disadari bahwa masih terdapat beberapa kekurangan dalam penelitian ini. Subjek menentukan lama waktu penggunaan internet berdasarkan pengakuan sendiri sehingga tidak menutup kemungkinan terdapat bias. Penilaian subjek bisa lebih tinggi dari yang sebenarnya ataupun lebih rendah dari yang sebenarnya.

Untuk penelitian selanjutnya, dapat diarahkan untuk mencari $94.7 \%$ faktor lainnya yang dapat memengaruhi adiksi internet sehingga pemahaman terkait faktor-faktor yang memengaruhi adiksi internet semakin lengkap. Faktor tersebut seperti depresi, gender, pencarian kebaruan, dan transendensi diri (June dkk., 2007), teman online, stres dan kesepian (Moslehpour \& Batjargal, 2013), 
karakteristik individu, variabel keluarga, sekolah, dan lingkungan (Lee dkk., 2019), maupun kepribadian, game online dan koneksi internet (Jiang dkk., 2017).

\section{Simpulan}

Penelitian ini telah berhasil membuktikan bahwa terdapat pengaruh signifikan leisure boredom dan religiusitas terhadap kecenderungan adiksi internet pada mahasiswa UIN Sunan Gunung Djati Bandung. Leisure boredom bersama-sama dengan tingkat religiusitas, memberikan pengaruh sebesar $5.3 \%$ terhadap seseorang untuk mengalami kecenderungan adiksi internet. Hasil itu memperlihatkan bahwa masih terdapat $94.7 \%$ factor lain selain leisure boredom dan religiusitas yang dapat memengaruhi adiksi terhadap internet seseorang.

Namun demikian, ketika leisure boredom dan religiusitas dipisahkan, hasilnya menjadi berbeda. Leisure boredom memiliki pengaruh terhadap kecenderungan adiksi internet pada mahasiswa UIN Sunan Gunung Djati Bandung. Sedangkan variabel religiusitas tidak memiliki pengaruh terhadap kecenderungan adiksi internet pada mahasiswa UIN Sunan Gunung Djati Bandung.

\section{Daftar Pustaka}

Asosiasi Penyelenggara Jasa Internet Indonesia. (2020). Penetrasi dan pelaku pengguna internet Indonesia. https://www.apjii.or.id.

Basri, A. S. H. (2014). Kecenderungan internet addiction disorder mahasiswa fakultas dakwah dan komunikasi ditinjau dari religiositas. Jurnal Dakwah, 15(2), 407-432. https://dx.doi.org/10.14421/jd.2014.15 209

Charlton, J. P., Soh, P. C. H., Ang, P. H., \& Chew, K. W. (2013). Religiosity, adolescent internet usage motives and addiction: An exploratory study. Information Communication and Society, 16(10), 1619-1638. https://doi.org/10.1080/1369118X.201 2.735251

Chung, S., Lee, J., \& Lee, H. K. (2019). Personal factors, internet characteristics, and environmental factors contributing to adolescent internet addiction: A public health perspective. International journal of environmental research and public health, 16(23), 4635. https://doi.org/10.3390/ijerph16234635

Gorgich, E. A. C., Moftakhar, L., Barfroshan, S., \& Arbabisarjou, A. (2018). Evaluation of internet addiction and mental health among medical sciences students in the southeast of Iran. Shiraz E Medical Journal, 19(1). e55561. https://doi.org/10.5812/semj.55561

Huber, S., \& Huber, O. W. (2012). The centrality of religiosity scale (CRS). Religions, 3(3), 710-724. https://doi.org/10.3390/rel3030710

lndriawati R., \& Wibowo, T. (2021): The pattern of internet use during the COVID19 pandemic in the 18-24 years age. Ann Trop Med \& Public Health, 22(1),

SP241101 http://doi.org/10.36295/ASRO.2021.24 1101

Iso-Ahola, S. E., \& Weissinger, E. (1990). Perceptions of boredom in leisure: conceptualization, reliability and validity of the leisure boredom scale. Journal of Leisure Research, 22(1), 117.

https://doi.org/10.1080/00222216.1990 .11969811

Jiang, Q., Huang, X., \& Tao, R. (2017). Examining factors influencing internet addiction and adolescent risk behaviors among excessive internet users. Health Communication, 33(12), 1434-1444. http://dx.doi.org/10.1080/10410236.20 17.1358241

June, K. J., Sohn, S. Y., So, A. Y., Yi, G. 
M., \& Park, S. H. (2007). Factors that influence internet addiction, smoking, and drinking in high school students. Taehan Kanho Hakhoe Chi, 37(6), 872-82.

http://dx.doi.org/10.4040/jkan.2007.37. 6.872

Kara, F. M. (2019). Internet addiction: relationship with perceived freedom in leisure, perception of boredom and sensation seeking. Higher Education Studies, 9(2), 131-140. https://doi.org/10.5539/hes.v9n2p131

Moslehpour, M., \& Batjargal, U. (2013). Factors influencing internet addiction among adolescents of Malaysia and Mongolia. Jurnal Administrasi Bisnis, 9(2), 101-116. https://doi.org/10.26593/jab.v9i2.1206. $\% 25 \mathrm{p}$

Nadeem, M., Buzdar, M. A., Shakir, M., \& Naseer, S. (2019). The association between muslim religiosity and internet addiction among young adult college students. Journal of Religion and Health, 58(6), 19531960. https://doi.org/10.1007/s10943018-0697-9

Pari, G., \& Jami, H. (2018). Correlates of value-orientation among adolescents: Role of internet addiction and demographic variables. Foundation University Journal of Psychology, 2(1), $1-28$. https://doi.org/10.33897/fujp.v2i1.43

Tao, R., Huang, X., Wang, J., Zhang, H., Zhang, Y., \& Li, M. (2010). Proposed diagnostic criteria for internet addiction. Addiction, 105(3), 556-564. https://doi.org/10.1111/j.13600443.2009.02828.x

We Are Social (2020, Februari). Digital 2020: Global digital overview. https://wearesocial.com/digital-2020

Weinstein, A., \& Lejoyeux, M. (2010). Internet addiction or excessive internet use. The American Journal of Drug and Alcohol Abuse, 36(5), 277-283. https://doi.org/10.3109/00952990.2010
.491880

Wijesingha, R., Leatherdale, S. T., Turner, N. E., \& Elton-Marshall, T. (2017). Factors associated with adolescent online and land-based gambling in Canada. Addiction Research and Theory, 25(6), 525-532. https://doi.org/10.1080/16066359.2017 .1311874

Young, K. S. (1998). Internet addiction: The emergence of a new clinical disorder. Cyberpsychology \& Behavior, 1(3), 237-244. https://doi.org/10.1089/cpb.1998.1.237

Young, K. S. (2004). Internet addiction: A new clinical phenomenon and its consequences. American Behavioral Scientist, 48(4), 402-415. https://doi.org/10.1177/000276420427 0278

Zhou, S. X., \& Leung, L. (2012). Gratification, loneliness, leisure boredom, and self-esteem as predictors of sns-game addiction and usage pattern among chinese college students. International Journal of Cyber Behavior, Psychology and Learning (IJCBPL), 2(4), 34-48. https://doi.org/10.4018/ijcbpl.2012100 103 